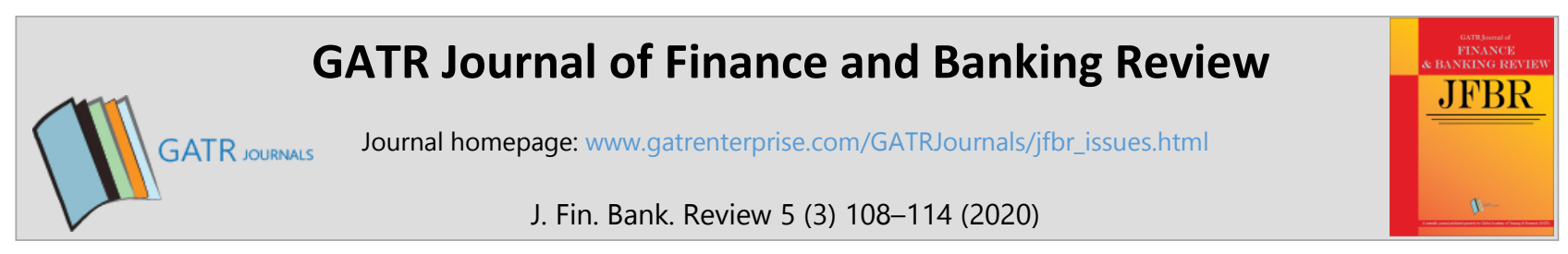

\title{
The Influence of ESG Disclosures on Firm Value in Thailand
}

\author{
Thanyaorn Yordudom*1, Muttanachai Suttipun ${ }^{2}$ \\ ${ }^{1,2}$ Faculty of Management Sciences, Prince of Songkla University, 90110, Songkhla, Thailand
}

\begin{abstract}
Objective - The study aimed (1) to investigate the extent and level of environmental, social and governance (ESG) disclosures of listed companies in Thailand Sustainable Investment (THSI) group from the Stock Exchange of Thailand (SET), and (2) to examine the influence of ESG disclosures on firm value.

Methodology/Technique - Population and samples were 60 listed companies in THSI group from the SET. Content analysis by word counting was used to quantify the extent and level of ESG disclosures in corporate annual reporting during 2015 to 2019, while firm value was collected by the market price. Descriptive analysis, correlation matrix, and multiple regression were used to analyze the data from the SET.

Findings - As the results, the extent and level of environmental, social, and governance disclosures were 309.91, 1196.12, and 1197.84 average words. The most common ESG disclosure was governance disclosure following by social and environmental disclosures. Moreover, the study found the positive influence of environmental and social disclosures on firm value, while there was a negative influence of governance disclosure on firm value.
\end{abstract}

Novelty - This study is the first THSI group study of ESG disclosure in Thailand.

Type of Paper: Empirical

Keywords: ESG Disclosures; Firm Value; Thailand.

Reference to this paper should be made as follows: Yordudom, T; Suttipun, M. (2020). The Influence of ESG Disclosures on Firm Value in Thailand, J. Fin. Bank. Review, 5 (3): 108 - 114. https://doi.org/10.35609/jfbr.2020.5.3(5)

JEL Classification: M40, M41, M48.

\section{Introduction}

Although corporate financial performance is important from an economic perspective, companies have to focus on environmental, social, and governance responsibilities in today's world. This is because if the companies aim only for profit without people and planet responsibilities, they will not be accepted by all of their stakeholders' demands. In the year 2015, therefore, the Stock Exchange of Thailand (SET) has adopted voluntary non-financial information disclosures namely environmental, social, and governance (ESG) disclosures that aim to support stakeholders' needs as well as corporate sustainable development. Some companies in the SET have been chosen by the SET as Thailand Sustainable Investment (THSI) firms that provide ESG disclosures into their annual reports.

\footnotetext{
* Paper Info: Revised: October 10, 2020

Accepted: December 31, 2020

* Corresponding author: Thanyaorn Yordudom

E-mail: y.thanyaorn@gmail.com

Affiliation: Faculty of Management Sciences, Prince of Songkla University, 90110, Songkhla, Thailand
} 
The importance of environmental, social, and governance disclosures allow the companies to develop more efficient business and if the companies have transparency and quality of internal management, the corporations will reduce the risk of fraud, cost of training new employees as well as increase the quality and productivity of the products per employee (Association of Thai Securities Companies, 2018). The ESG disclosures have been used as the guideline from Global Reporting Initiative (GRI) Standards.

One advantage from the corporate ESG disclosures are to increase firm value (Barnett and Salomon, 2012). This advantage can be explained by using signaling theory. It is because the ESG disclosures can close or reduce information asymmetry between the corporations and investors, therefore, the investors will positively react, if the corporations serve their demands including ESG disclosures. However, there are few prior related studies in Thailand that examined the influence of the environment, social, and governance disclosures on firm value (Hodkam, 2016; Huaypad, 2019). Moreover, the literature provided conflict results. For example, Brecht et al. (2018) found a positive influence of non-financial information disclosures on firm value by investors. The reason is that the investors have interested in the disclosures and they reflect on decision-making by investment into the corporations. On the other hand, ESG disclosures cost and reduce the corporate performance that negatively affects investors' reaction (Kirkerud and Tran, 2019). In addition, Busru and Shanmugasundaram (2016) did not found any influence of the environment, social, and governance disclosures on firm value.

From the research problem above, this study aimed to investigate the extent and level of environmental, social, and governance (ESG) disclosures of listed companies in THSI group from the Stock Exchange of Thailand (SET), and (2) to examine the influence of ESG disclosures on firm value. To remind the research structure, this study is begun with a literature review consisted of ESG disclosures in Thailand, and hypothesis development. Next, methods are explained by using population and sample, data collection, variable measurement, and data analysis. Findings and discussions are tested and indicated in the next section. Finally, a conclusion and suggestion for future study are provided.

\section{Literature Review}

\subsection{ESG disclosures in Thailand}

ESG disclosures are developed and supported by the Stock Exchange of Thailand (SET) and the disclosures are part of corporate sustainable development. The main importance of ESG disclosures is (1) the process of observing and consolidate data on sustainability to serve corporate evaluate and improve business efficiency including reduce risks and create opportunities to earn income or reduce operating expenses, (2) the process that analyzes stakeholders and support to communicate and comprehension about issues that stakeholders react' which corporate manage properly to maintain their competitiveness, (3) the credibility of the corporate with the reflecting on the role and responsibility along with the representation of performance for corporate growth on sustainable, and (4) the tool to reflect the potential of the business and attraction to investors who want to invest in quality corporate and create long-term returns. Many companies in the SET have been chosen by the SET as Thailand Sustainable Investment (THSI) firms that provide ESG disclosures into their annual reports.

ESG disclosures are classified by eleven points within three dimensions of environmental, social, and governance. The first dimension, environment disclosure is pointed and separated as energy management, water management, waste management, and greenhouse gas management. The second dimension, social disclosure consists of human resources to be equitable and fair, take care of safety and occupational health including having a good relationship with communities consist of treatment of workers/employees, the responsibility to customers, and social / community development. Finally, governance disclosure provides good corporate governance policy, transparent operation, resist corruption, and protecting the benefit of 
stakeholders, which dimension consists of good governance, sustainability risk management, supply chain management, and innovation. 2.2

\section{Hypothesis development}

To consider the influence of environmental disclosure on firm value, most prior related studies found a positive influence (Jagannathan et al., 2017; Yoon et al., 2018; Almeyda and Darmansyah, 2019). The logical reason for positive influence of environmental disclosure on the firm value measured by market price is because the companies try to provide their activities and activities to serve stakeholders' demands, thus, their stakeholders including the investors will positively react on investment and making a decision (Jagannathan et al., 2017). However, Hodkam (2016) did not find any influence of environmental disclosure on the firm value measured. Therefore, to find out the answer to the research question, the study hypothesizes that:

H1: Environmental disclosure has a positive effect on the firm value measured by the market price.

The most prior related literature found the positive influence of social disclosure on firm value (Caroline, 2012; Lee, 2016; Khajavai et al., 2018; Yoon et al., 2018). This is because the investors positively react to corporate conduct activities and actions for society (Yoon et al., 2018), and the impact of corporate social responsibility can reduce the stock price crash risk (Lee, 2016). However, there were some studies finding the negative influence of social disclosure on firm value (Di Donato and Izzo, 2012; Barnea and Rubin, 2006). It is because corporate activities and actions on social responsibility provide more cost to the corporations that reduce shareholder' income and firm value. Therefore, the study aims to hypothesize that:

\section{H2: Social disclosure has a positive effect on firm value measured by the market price.}

Many previous related studies found the positive influence of governance disclosure on firm value (Yoon et al., 2018; Kosanlawit, 2019; Malik, 2012) because corporate governance is an important factor for a company's market price. Moreover, corporate governance disclosure is mandatory reporting in many countries. Therefore, corporations can improve corporate governance for a higher score to increase firm value. However, Busru and Shanmugasundaram (2016) did not find any possible influence of governance disclosure on the firm value. Therefore, the study aims to hypothesize that:

H3: Governance disclosure has a positive effect on the firm value measured by the market price.

\section{Methods}

The population and samples were 60 listed companies of THSI group in the SET. Data from corporate annual reports from 2015 to 2019 was used to collect. The data collection was separated into two sections that are (1) general information of corporate such as name, age of corporate, return on the asset, debt to equity, liquidity, size of corporate, industry type, and market price, and (2) the extent and level of environmental, social, and governance disclosures.

There were three groups of variables used in this study which are ESG disclosures as independent variables, the firm value measured by market price as the dependent variable, and corporate characteristics as control variables. In terms of independent variables, ESG disclosures were separated into three variables as environmental, social, and governance disclosures (Stock Exchange of Thailand, 2015). Firm value as the dependent variable in this study was measured by the market price. Moreover, corporate characteristics such as the size of the company, age of the company, profitability, leverage, liquidity, and industry type were measured by the prior related studies (Suttipun and Sittidate, 2014; Hodkam, 2016; Huaypad, 2019). All variables' measurement used in this study was indicated in Table 1. 
Table 1. Variable's measurement

\begin{tabular}{ccc}
\hline Independent Variables & Notation & Measurement \\
\hline Environmental disclosure & ED & Word count \\
Social disclosure & SD & Word count \\
Governance disclosure & GD & Word count \\
\hline Dependent Variable & Notation & Measurement \\
\hline Firm value & FV & Market price \\
\hline Control Variables & Notation & Measurement \\
\hline Corporate size & SIZE & Total assets (Million bath) \\
Corporate age & AGE & Age of corporate (Year) \\
Profitability & ROA & Return on asset \\
Leverage & DE & Debt to equity \\
Liquidity & CR & Current Ratio \\
Industry type & TYPE & Dummy variables as 1 = Agro \& Food Industry, 2 \\
& \multicolumn{2}{c}{ Consumer Products, 3 = Financials, $4=$} \\
& $\quad$ Industrials, $5=$ Property \& Construction, $6=$ \\
& Resources, $7=$ Services, and $8=$ Technology \\
\hline
\end{tabular}

Within two main objectives, descriptive analysis was used to investigate the extent and level of ESG disclosures, while the correlation matrix was used to test for multicollinearity between the variables. Finally, multiple regression was used to test for the influence of ESG disclosures on the firm value measured by the market price. The regression equation used was as follows:

$\mathrm{FV}=\beta 0+\beta 1 \mathrm{ED}+\beta 2 \mathrm{SD}+\beta 3 \mathrm{GD}+\beta 4 \mathrm{SIZE}+\beta 5 \mathrm{AGE}+\beta 6 \mathrm{ROA}+\beta 7 \mathrm{DE}+\beta 8 \mathrm{CR}+\beta 9 \mathrm{TYPE}+\varepsilon$

\section{Results and Discussions}

From 60 samples, 300 annual reports from 2015 to 2019 were used in this study. To investigate the extent and level of ESG disclosures, table 2 indicates that the extent and level of environmental, social, and governance disclosures were 309.91, 1196.12, and 1197.84 average words. The most common ESG disclosure was governance disclosure following by social and environmental disclosures. The results of word count that the social disclosure and governance have a similar word count because the Stock Exchange of Thailand has a mandatory of the social and governance disclosure, but the environmental disclosure has a voluntary one. So, the environmental disclosure less than the social and governance disclosure.

Before conducting the multiple regression analysis, the assumptions that the data was no multicollinearity among the variables included in the analysis was first tested. Table 2 demonstrate the correlation matrix used to test for multicollinearity between the ten variables used in this study, consisting of one dependent variable, three independent variables, and six control variables. Based on a fixed-effects model for panel testing, the variance inflation factor (VIF) of the correlation matrix between the variables was 1.759 , which indicates that there was no multicollinearity, which would be indicated by a VIF exceeding 10 (Silpcharu, 2010) and the value of the relationship between the variables should not exceed 0.750 . From the correlation coefficients between the ten variables used in this study, there were significant positive correlations between FV, ED, SD, SIZE, and AGE at either 0.01 or 0.05 levels, while there was no correlation between FV, GD, ROA, DE, CR, and TYPE at 0.05 level. 
Table 2. Correlation matrix

\begin{tabular}{|c|c|c|c|c|c|c|c|c|c|c|}
\hline & $\mathrm{FV}$ & ED & SD & GD & SIZE & $\mathrm{AGE}$ & ROA & $\mathrm{DE}$ & CR & TYPE \\
\hline $\mathrm{FV}$ & 1 & $.313 * *$ & $.302 * *$ & -.068 & $.259 * *$ & $.473 * *$ & .049 & .081 & -.111 & .041 \\
\hline ED & & 1 & $.571 * *$ & $.269 * *$ & .057 & $.216^{* *}$ & .013 & -.084 & -.008 & -.100 \\
\hline SD & & & 1 & $.368 * *$ & $.149 * *$ & .106 & $-.131 *$ & $.135 *$ & $-.171 * *$ & .022 \\
\hline GD & & & & 1 & $.201 * *$ & .048 & $-.266 * *$ & $.175^{* *} *$ & -.009 & -.098 \\
\hline SIZE & & & & & 1 & $.511 * *$ & $-.305 * *$ & $.729 * *$ & $-.310 * *$ & $-.283 * *$ \\
\hline AGE & & & & & & 1 & -.107 & $.369 * *$ & $-.222 * *$ & $-.381 * *$ \\
\hline ROA & & & & & & & 1 & $.378 * *$ & $.187 * *$ & .060 \\
\hline $\mathrm{DE}$ & & & & & & & & 1 & $-.450 * *$ & $-.272 * *$ \\
\hline $\mathrm{CR}$ & & & & & & & & & 1 & $.169 * *$ \\
\hline TYPE & & & & & & & & & & 1 \\
\hline Mean & 52.27 & 309.91 & 1196.12 & 1197.84 & 301705.76 & 35.72 & 6.89 & 1.95 & 1.59 & - \\
\hline SD & 80.19 & 261.46 & 631.83 & 530.13 & 685984.40 & 17.96 & 5.60 & 2.27 & 1.28 & - \\
\hline VIF & - & 1.740 & 1.759 & 1.297 & 2.552 & 1.577 & 1.238 & 2.715 & 1.314 & 1.242 \\
\hline Tole & - & .575 & .569 & .771 & .392 & .634 & .808 & .368 & .761 & .805 \\
\hline
\end{tabular}

** is significant at 0.01 level, and $*$ is significant at 0.05 level

To examine for the influence of ESG disclosures on firm value, table 3 indicates that both ED and SD had a positively significant influence on FV at 0.05 and 0.01 levels, while GD had a negatively significant influence on FV at 0.01 level. In addition, there was a positive significant relationship between control variables used in this study (i.e. SIZE, AGE, and TYPE) and FV at the 0.01 level, while DE was a negative significant relationship with FV at the 0.05 level. The model provided a high level of independence and control variables' ability to forecast dependent variable because Adjust R square and R square were 38.30, and 40.20 percent.

Table 3. Multiple regression

\begin{tabular}{|c|c|c|c|c|}
\hline Variables & $\mathrm{B}$ & Beta & $\mathrm{t}$ & Sig. \\
\hline -Constant- & -81.919 & - & -3.926 & $.000 * *$ \\
\hline ED & .036 & .118 & 1.976 & $.049 *$ \\
\hline SD & .031 & .244 & 4.053 & $.000 * *$ \\
\hline GD & -.028 & -.185 & -3.570 & $.000 * *$ \\
\hline SIZE & $2.358 \mathrm{E}-5$ & .202 & 2.781 & $.006 * *$ \\
\hline AGE & 2.107 & .472 & 8.276 & $.000 * *$ \\
\hline ROA & 1.076 & .075 & 1.489 & .138 \\
\hline $\mathrm{DE}$ & -5.388 & -.152 & -2.037 & $.043 *$ \\
\hline $\mathrm{CR}$ & -1.479 & -.024 & -.454 & .650 \\
\hline TYPE & 8.402 & .224 & 4.423 & $.000 * *$ \\
\hline R Square & \multicolumn{4}{|c|}{.402} \\
\hline Adj. R Square & \multicolumn{4}{|c|}{.383} \\
\hline F-value (sig.) & \multicolumn{4}{|c|}{$21.659(.000 * *)$} \\
\hline $\mathrm{N}$ & \multicolumn{4}{|c|}{300} \\
\hline
\end{tabular}

** is significant at 0.01 level, and $*$ is significant at 0.05 level

The finding of a positive influence of environmental disclosure on firm value was consistent with Jagannathan et al. (2017), Almeyda and Darmansyah (2019), and Yoon et al. (2018). This is because investors were interested in the risk of the environment in the era of social media and supporting positive corporate conduct activities for the environment.

The result of the positive influence of social disclosure in this study was consistent with Caroline (2012), Yoon et al. (2018), Lee (2016), and Khajavai et al. (2018). It is because investors supporting positive of corporate conduct activities for social and the impact of social responsibility reduce the stock price crash risk. 
And the finding of the negative influence of governance disclosure on the firm value measured by market price because governance disclosure made mandatory by the Stock Exchange of Thailand. So, governance disclosure demonstrates advantages and disadvantages, but the result of this study demonstrates with corporate signal negative to investors. Therefore, from the signaling theory that when corporate demonstrate non-financial performance, it renders to investors and stakeholders access the resource more and reduce conflicts about accessing the resource. So, when the corporate demonstrates an increase in non-financial performance, it will be an increase in market price as well as this study found the positive and significance of environmental disclosure and social disclosure.

\section{Conclusions and Suggestions for Future Study}

Within two main questions as (1), what is the extent and level of environmental, social, and governance disclosures of listed companies in THIS group from the SET, and (2) which ESG disclosures can influence firm value, the study found that the environmental, social, and governance disclosures were 309.91, 1196.12, and 1197.84 average words. The most common ESG disclosures were governance disclosure following by social and environmental disclosures. Moreover, both environmental and social disclosures were a positive and significant influence on firm value, while there was the negative influence of governance disclosure on firm value.

The study's findings provide several contributions and implications. First, the results can guide the companies to pay attention to environmental and social disclosures because they can influence investors' reactions. Second, the study's findings are able to explain how and why the signaling theory can be used to test the influences of environmental, social, and governance disclosures on firm value whether the corporate stakeholders have a right to be responded by corporate' actions and activities, and the benefit of corporate responsibility is greater reputation and loyally as well as better performance and value. Finally, the study's results also demonstrate the guideline from the SET providing benefit to the corporations and their stakeholders, therefore, ESG disclosures can be changed from voluntary to mandatory disclosures in Thailand as well as the other countries.

There are some limitations to this study's findings. Firstly, the sample of this study is a limitation because the study interested only THIS group and did not include the non-THSI group. Second, the Thailand Sustainability Investment (THSI) included both the main capital market and the alternative capital market but this study used the only main market. Finally, this study cannot compare that ESG disclosure with another group in ASIAN. Therefore, the suggestions for the study in future are the collect data both the main capital market and the alternative capital market, the collected data for the sample of the non-THSI group and compare the difference between the group in Thailand and comparisons of corporate demonstrate ESG disclosure with corporate in ASEAN.

\section{References}

Almeyda, R., \& Darmansya, A. (2019). The Influence of Environmental, Social, and Governance (ESG) Disclosure on Firm Financial Performance. IPTEK Journal of Proceedings Series, (5), 278-290. DOI. 10.12962/j23546026.y2019i5.6340.

Association of Thai Securities Companies. (2018). Good Corporate Governance and Sustainability Development. Retrieved from https://www.sec.or.th/TH/Pages/LawandRegulations/HandbooksGuidelines.aspx.

Barnea, A., \& Rubin, A. (2006). Corporate Social Responsibility as a Conflict between Shareholders. CIBC Centre for Corporate Governance and Risk Management.

Barnett, M. L., \& Salomon, R. M. (2012). Does it pay to be really good? Addressing the shape of the relationship between social and financial performance. Strategic Management Journal, 33(11), 1304-1320. DOI. 10.2307/41679849. Busru, S., \& Shanmugasundaram, G. (2017). Corporate Disclosure Scores and Share Price Reaction: Empirical Study of Indian Listed Firms (Post Satyam Period). Available at SSRN 2926897. DOI.10.2139/ssrn.2926897. 
Brecht, D.V. (2018). Exploring the link between Environmental, Social and Governance (ESG) disclosure and market value of the firm: Evidence from Thai listed companies. ASEAN Journal of Management \& Innovation, 5(1), 95-106. Flammer, C. (2012, May). Corporate social responsibility and stock prices: The environmental awareness of shareholders. In fourth annual research conference, Yale University (Vol. 16). https://doi.org/10.5465/amj.2011.0744. Deegan, C., \& Gordon, B. (1996). A study of the environmental disclosure practices of Australian corporations. Accounting and business research, 26(3), 187-199.https://doi.org/10.1080/00014788.1996.9729510.

Izzo, M. F., \& di Donato, F. (2012). The relation between corporate social responsibility and stock prices: an analysis of the Italian listed companies. Available at SSRN 1986324.

Flammer, C. (2012, May). Corporate social responsibility and stock prices: The environmental awareness of shareholders. In fourth annual research conference, Yale University (Vol. 16). DOI.10.5465/amj.2011.0744.

Gray, R., Collison, D., \& Bebbington, J. (1998). Environmental and social accounting and reporting. Financial reporting today, 179-214.

Hodkum, S., \& Chanruang, S. (2017). The Study of Relationship Between the Level of Sustainabilty Report Disclosure and Security Prices of listed Companies in the Stock Exchange of Thailand. Journal of Global buSineSS review, 19(1), 47-54.

Huaypad, S. (2019). The Relationship between the Quality of Social Responsibility Disclosure and Stock Price of Firms Listed in the Stock Exchange of Thailand. Journal of Modern Management Science, 12(2), 53-67. https://doi.org/10.14456/jmms.2019.12.

Jagannathan, R., Liberti, J., Liu, B., \& Meier, I. (2017). A Firm's Cost of Capital. Annual Review of Financial Economics, 9, 259-282. https://doi.org/10.1146/annurev-financial-110716-032429

Khajavai, S., Taghizadeh, R., SadeghzadehMaharluie, M., \& Rezaee, G. R. (2018). Corporate Social Responsibility and Stock Price Crash Risk: Evidence from an Emerging Market. Iranian Journal of Accounting, Auditing \& Finance, 2(1). https://doi.org/10.1108/MF-10-2015-0278.

Kirkerud, S., \& Tran, K. T. (2019). Value relevance of ESG: Is ESG performance value relevant for stock prices in Europe? (Master's thesis, OsloMet-Oslo Metropolitan University).

Kosanlawit, T., \& Ugsornwong, K. (2019). Relationship between Corporate Governance and Market Value of Firms: A Case Study of Listed Companies in the Stock Exchange of Thailand and the Market for Alternative Investment. Journal of Management Science Ubon Ratchathani University, 8(15), 82-99.

Lee, M. T. (2016). Corporate social responsibility and stock price crash risk. Managerial Finance.https://doi.org/10.1108/MF-10-2015-0278.

Jhandir, S. U. (2012). Relationship between corporate governance score and stock prices: Evidence from KSE-30 index companies. International Journal of Business and Social Science, 3(4).

Silpcharu, T. (2010). Research and Statistical Analysis with SPSS. (11th Edition). Nonthaburi: S.R. Printing Mass product Co., Ltd.

Suttipun, M., \& Sittidate, N. (2014). Corporate Social Responsibility Reporting and Operation Performance of Listed Companies in the Stock Exchange of Thailand. Songklanakarin Journal of Social Science and Humanities, 22(1), 1-24.

The Stock Exchange of Thailand (SET). (2019). ESG Disclosure. Retrieved from https://www.setsustainability.com/page/esg-disclosure.

Yoon, B., Lee, J. H., \& Byun, R. (2018). Does ESG performance enhance firm value? Evidence from Korea. Sustainability, 10(10), 3635. https://doi.org/10.3390/su10103635. 